\title{
La muerte en el mundo clásico
}

\author{
Death in the classical word
}

\author{
María Teresa Román López*
}

\begin{abstract}
RESUMEN
¿Cómo se concibe la muerte en el mundo clásico? El tema de la muerte no parece haber sido objeto de gran preocupación por parte del mundo clásico. Hades

(Plutón) y Perséfone (Proserpina) presidían las moradas infernales: poblaciones de pálidos fantasmas, almas sin memoria despojadas de sentido.

Según la sentencia que se le imponía, el alma era conducida a las Praderas de Asfódelos, si no son virtuosas ni malas; arrojadas al Tártaro, si son malvadas; si son virtuosas eran conducidas a los Campos Elíseos, gobernados por Cronos. En el mundo griego, la doctrina de la transmigración formaba parte del entramado doctrinal del orfismo. Cicerón afirma con toda claridad y contundencia que el alma es inmortal, recurriendo a los elementos pitagóricos y platónicos.
\end{abstract}

PALABRAS CLAVE: Muerte, Mundo Clásico, deidades de la muerte, el mundo de los muertos, inmortalidad, transmigración.

\begin{abstract}
How is death conceived in the classical world? The classical world does not seem to have been very concerned about the topic of death. Hades (Pluto) and Persephone (Proserpina) presided over the infernal world: populations of pale ghosts, souls without memory, robbed of their senses. Depending on the sentence imposed, the soul was led to the Fields of Asphodels, if it was neither virtuous nor bad; thrown into the Tartarus if it was evil; and led to the Elysian Fields, governed by Cronos, if it was virtuous. In the Greek world, the doctrine of transmigration was part of the doctrinal fabric of Orphism. Cicero states quite clearly and forcefully that the soul is immortal, appealing to Pythagorean and Platonic elements.
\end{abstract}

KEYWORDS:

Death. Classical world. Deities of death. World of the dead. Immortality. Transmigration.

\footnotetext{
* Departamento de Filosofía de la UNED. Paseo Senda del Rey, 17. 28040 Madrid.

E-mail: mroman@fsof.uned.es
} 


\section{INTRODUCCIÓN}

«No puede negarse, que si de alguna realidad en el mundo puede decirse que a nadie deja frío, que hace estremecerse a todos, esa realidad es la muerte. Los antiguos griegos y romanos tomaban en serio la muerte, y no se dudaba que el hombre estaba sometido a ella, como a uno de tantos soberanos de la existencia mortal».

KARL KERÉNYI

¿Qué clase de suceso es ese, que representa el caso más definitivo y serio, con el que todo el mundo ha de enfrentarse de forma segura, pero en una hora incierta? ¿Qué sucede, en el fondo, cuando un ser humano muere? ¿En qué consiste el pináculo de lo ignoto? Para Epicuro (341-270 a.C.) la muerte no es más que una disgregación de los átomos materiales de los que estamos hechos y que, por eso, no es nada. Él aconseja a su discípulo Meneceo: «la muerte no va nada con nosotros, justamente porque cuando existimos nosotros la muerte no está presente, y cuando la muerte está presente entonces nosotros no existimos» (Epístola a Meneceo, 125). No obstante, para el filósofo griego la muerte estaba siempre ahí justamente de un modo significativo. Esto ya lo advirtieron, dado el interés que mostró por el tema, sus detractores de la antigüedad. Por su parte, Platón (428-348 a.C.) manifiesta que es la última oportunidad, la principal porque encierra en sí y justiprecia a las anteriores, que se le brinda a la persona para exteriorizar su sometimiento a las divinidades. En efecto, el gran filósofo ateniense pone en boca de Sócrates (470-399 a.C.) lo siguiente: «obraría yo indignamente, $\mathrm{si}$, al asignarme un puesto los jefes que vosotros elegisteis para mandarme a Potidea, en Anfípolis y en Delion, decidí permanecer como otro cualquiera allí donde ellos me colocaron y corrí, entonces, el riesgo de morir, y en cambio ahora, al ordenarme el dios, según he creído y aceptado, que debo vivir filosofando y examinándome a mí mismo y a los demás, abandonara mi puesto por temor a la muerte o a cualquier otra cosa» (Apología de Sócrates, 28e-29a).

El tema de la muerte fue algo que no parece haber sido objeto de gran preocupación por parte del mundo griego, mientras los asuntos de esta esfera fuesen desenvolviéndose de una manera aceptable: «El mundo de los muertos era un lugar sombrío y tenebroso adonde nadie deseaba ir. Por otra parte, el anhelo de inmortalidad no era característico en el término medio de los griegos, no siendo solamente los pitagóricos, sino también otros filósofos, los que asociaban lo infinito y lo que carecía de límites con la idea del mal. El gusto general se inclinaba más bien por las cosas finitas y bien proporcionadas, y por tanto, en el caso de la vida humana, por aquella plenitud que pudiese lograrse viviendo hasta una edad avanzada con el disfrute de una posición holgada, dejando descendencia y muriendo rodeado de prestigio» 1 .

\footnotetext{
1 E.O. James (dir.), Historia de las religiones, Vergara, vol. 1, Barcelona, 1963, p. 371.
} 
La idea romana del más allá, aparece expuesta en «El sueño de Escipión», final del tratado de Cicerón Sobre la República; en él Escipión Africano el Joven cuenta un sueño en el que había visto a su abuelo, Escipión Africano el Viejo:

«Al oír estas palabras, a pesar del estremecimiento que sentía no tanto por el miedo de la muerte, cuanto de las insidias de los míos, le pregunté si vivía él y mi padre Paulo y los demás que nosotros consideramos como extinguidos. "Ciertamente, viven, me respondió, todos los que salieron volando de las ataduras de los cuerpos, como de una cárcel; en cambio, eso que vosotros llamáis «vida» es una muerte. ¿Por qué no miras a tu padre, Paulo, que se acerca a ti? ». Cuando yo lo vi, empecé a derramar un torrente de lágrimas; pero él abrazándome y besándome contuvo mi llanto.

Apenas, reprimido el llanto, pude empezar a hablar, le pregunté: « ¡Oh el mejor, y el más venerable de los padres!, puesto que esto es la vida, como oigo decir a mi abuelo el Africano, ¿por qué permanezco en la tierra? ¿Por qué no me apresuro a salir de ella y venir con vosotros? ¿ ¿No puede ser me respondió, mientras este Dios, cuyo templo en este mundo que contemplas, no te libere de esas amarras del cuerpo, no puede tener acceso hasta aquí. Porque los hombres han sido engendrados con el fin de que cuiden del globo que ves en medio de este templo, y se llama tierra. Y se les ha dado un alma sacada de aquellos fuegos eternos, que vosotros llamáis constelaciones y estrellas, que son globos de contornos uniformemente redondos, animados por mentes divinas y efectúan con una rapidez maravillosa sus órbitas circulares. Por tanto, tú, Publio, y todos los hombres piadosos tenéis que conservar el alma en el reducto del cuerpo, ni podéis salir de la vida humana sin la orden de quien os ha dado este alma, para que no parezca que abandonáis el puesto que Dios os ha asignado entre los hombres.

Pero tú, Escipión, como tu abuelo aquí presente, como yo que te engendré, cultiva la justicia y obra con piedad, virtud que siendo grande hacia los padres, y los parientes, lo es más con respecto a la patria. Esa es la vida que allana el camino hasta el cielo, y esta asamblea de los que vivieron, y liberados del cuerpo habitan este lugar que tú ves -era éste un círculo brillante con un candor espléndido en medio de unas llamas- que vosotros, según el nombre recibido de los griegos, llamáis "vía láctea». Todos los objetos que yo contemplaba desde allí me parecían maravillosos y encantadores. Eran unas estrellas que nunca hemos visto desde la tierra, y la grandeza de todas ellas tal como no podemos sospechar. La última y la más próxima a la tierra era la más pequeña, y brillaba con un reflejo de luz ajena. Los globos estelares sobrepasaban en mucho el tamaño de la tierra. La misma tierra me pareció tan pequeña, que me causó pena de ver vuestro imperio que no ocupa más que un punto de ella [...] Yo miraba estupefacto todas aquellas maravillas, cuando vine en mí:-¿Qué es esto? - pregunté-, ¿qué sonido tan intenso y tan dulce llena mis oídos?- Es el sonido -me respondió él- que se produce por el impulso y el movimiento de las mismas esferas, formado por intervalos impares, pero distintos en su debida proporción, que combinados los agudos con los graves, hace de esos tonos equilibradamente variadas melodías. No pueden en efecto realizarse esos movimientos tan grandes en silencio, y en virtud de una ley natural las esferas externas emiten desde un lado sonido graves y desde el otro agudos. Por lo tanto, la órbita superior del cielo portadora de estrellas, más rápida que las otras esferas en su revolución, se mueve con un sonido agudo y mantenido; la esfera lunar da, por el contrario, el sonido más grave. Porque la Tierra, la novena, permaneciendo inmóvil, está fija en su base, abrazando el centro del mundo. Pero las otras esferas móviles entre las cuales hay dos con el mismo impulso pro- 
ducen siete tonos diferentes, número que en todas las materias tiene significación esencial. Imitando estas armonías algunos hombres doctos con instrumentos músicos o con sus voces, se prepararon la vuelta a este lugar; como otros, que dotados de agudos ingenios se aplicaron en su vida humana al estudio de las cosas divinas [...] «Sí, esfuérzate, y ten entendido que tú no eres mortal, sino tu cuerpo; porque tú no eres el que manifiesta la apariencia exterior, sino el alma de cada uno es el ser verdadero, no la figura que puede señalarse con el dedo. Ten presente que eres un ser divino, porque ser divino es el principio que vive, que siente, que se acuerda, que prevé, y gobierna y modera al cuerpo, sobre el que está colocado, como el primero de los dioses dirige y gobierna al mundo, y al igual que el Dios eterno mueve al mundo perecedero en parte, un alma inmortal mueve al cuerpo corruptible» (Sobre la República, VI, 14-26).

\section{LAS DIVINIDADES DE LA MUERTE}

En el mundo griego, Hades (Plutón) y Perséfone (Proserpina) presidían el insatisfactorio y tenebroso reino de las Sombras²: poblaciones de pálidos fantasmas, almas sin memoria despojadas de sentido. El espectro de Aquiles llega decir a Ulises: «No intentes consolarme de la muerte, noble Odiseo. Preferiría estar sobre la tierra y servir en casa de un hombre pobre, aunque no tuviera gran hacienda, que ser el soberano de todos los cadáveres, de los muertos» (Odisea XI, 490). Morada tenebrosa y lúgubre, las regiones infernales eran, en el mundo clásico, el refugio de las almas, que separadas de su cuerpo, habían concluido su existencia terrena:

«Salieron de las profundas moradas del Erebo, emocionados por su gemido, las tenues sombras y los espectros de todos los privados de luz [...] Empezaron a salir madres, esposos, cuerpos de héroes magnánimos privados de vida, niños, muchachas muertas antes del himeneo, gentes de toda clase colocadas en las hogueras ante los ojos de sus deudos. Y en torno a todo ello, extendióse un negro barro, y los ásperos cañaverales del Cocito, y la maldita laguna de agua pestilente que acabó encadenándolos, y el tenebroso Estigia, que los rodeó con sus aguas hasta nueve veces.

Asimismo se llenaron de estupor las propias moradas de la muerte y el fondo del Tártaro; como también las Euménides, de cabellos entrelazados por azules serpientes; y cesó de ladrar el mismo Cerbero, con sus tres fauces abiertas; y la rueda de Ixión se detuvo con el viento que la hace girar» (Geórgicas, 470-480).

Tánatos, proveedora natural de Hades e hija de Nyx, divinidad de las tinieblas y hermana de Hipnos ${ }^{3}$, forma parte, según Hesíodo (s. VIII a.C.), de ese tiempo primordial de los nacimientos solitarios y las separaciones en el que Eros está fuera

2 La vida en el más allá, tal y como está descrita en la epopeya homérica, es sólo el triste y pálido reflejo de la vida en la tierra, que los espectros no cesan de lamentar. Posteriormente, la renovación de los misterios eleusinos y dionisíacos propician la reactivación de la creencia en una vida de ultratumba feliz.

3 Según Mircea Eliade: «Desde el momento que Hypnos es el hermano de Thanatos, se comprende por qué, tanto en Grecia como en la India y en el gnosticismo, la acción de «despertarse» tenía una significación «soteriológica»». Mito y realidad, Guadarrama, Madrid, 1973, p. 143. 
de juego: sola y sin dormir con nadie, la Noche, nacida ella misma del $\mathrm{Caos}^{4}$, engendra a la detestable Muerte, al Tránsito y a la negra Ker: «Parió la Noche al maldito Moros, a la negra Ker y a Tánatos; parió también a Hipnos y engendró la tribu de los Sueños» (Teogonía, 212). Tánatos se inscribe aquí en un siniestro linaje en el que se destacan las Moiras o Parcas, Eris ${ }^{5}$ y Némesis: «Parió igualmente a las Moiras y las Keres, vengadoras implacables: a Cloto, a Láquesis y a Átropo [...] También alumbró a Némesis [...] Después de ella tuvo al Engaño, la Ternura y la funesta Vejez, y engendró a la astuta Eris» (Teogonía, 215, 220 y 225).

No obstante, esta muerte no es la única imagen que de ella se hizo el mundo griego: otras deidades se suman para mostrar sus diversos aspectos. En primer término, Hades, o entre los romanos, Plutón, hijo de Rea y del feroz Cronos (Saturno), deidad cruel, iracunda, inflexible y odiosa (llíada, IX,158), guardián de las almas, vigilante implacable que no permite que nadie salga de sus dominios, manifestando en algunas ocasiones cierto pavor ante la posibilidad de que se resquebraje la tierra y puedan quedar a la vista sus tenebrosas y lóbregas moradas: «Y se asustó, debajo de la tierra, Aïdoneo, el señor de los muertos [...] y lanzó un grito, no fuera a ocurrir que Posidón, el batidor del suelo, por encima la tierra le hendiera y a la vista quedaran de los mortales y los inmortales las moradas mohosas y horrendas que hasta los mismos dioses aborrecen" (llíada XX, 61-65). Detestado por todos, incluso por las deidades, Hades gobierna sobre este ámbito tenebroso, como señala Hesíodo: «De bronce eran sus armas, de bronce sus casas y con bronce trabajaban; no existía el negro hierro. También éstos, víctimas de sus propias manos, marcharon a la vasta mansión del cruento Hades" (Trabajos y días, 153). El azar convertirá a Hades en soberano del mundo de las sombras: «Pues, tres hermanos de Crono hemos nacido a los que Rea parió; Zeus y yo y, el tercero, Hades que es soberano de los muertos; y en tres partes todo está repartido y cada uno participa ya de su prerrogativa, a saber: yo obtuve, al ser echadas las suertes, habitar la mar canosa y Hades obtuvo las brumosas sombras, y a Zeus le tocó el ancho cielo» (llíada, XV,187-190).

Perséfone ${ }^{6}$ (la «augusta», la «temible», la «pura», la «sabia») o Coré ${ }^{8}$ (la «hermosa niña soberana de los muertos», la «doncella»), o, entre los romanos,

${ }^{4}$ Para Hesíodo y otros poetas griegos, el Caos era el despertar del abismo insondable, del que surgieron Gea, El Erebo, la Noche y el Tártaro.

5 Es hija de la Noche y madre del Olvido, el Hambre, las Penas, las Querellas, el Engaño y la ilegalidad.

6 «Perséfone no es una divinidad puramente infernal. Antes de su unión con Hades, vivía sobre la tierra con su madre Deméter, que la concibiera de Zeus. Entonces su nombre era Core. Es probable que, en sus orígenes, madre e hija estuviesen confundidas en una sola e idéntica divinidad. En efecto, los demonios de Deméter se extienden, como hemos dicho, por igual, a la superficie y al interior de la tierra. Posteriormente sufrió un desdoblamiento, y sus atribuciones subterráneas pasaron a una diosa distinta, emanada de la divinidad primitiva. Así se explica el episodio de Core-Perséfone». F. Guirand (dir.), Mitología general, Labor, Madrid, 1965, p. 237.

7 En Crátilo (404d), Platón se refiere a Perséfone así: «Así pues la Diosa sería llamada con exactitud Pherépapha, en virtud de su sabiduría y su «contacto con lo que se mueve»».

8 «Perséfone - quien fue conocida también como Core, «la doncella»— fue concebida de Zeus. Su madre era Deméter, la diosa cretense de la agricultura y del suelo productivo. Se nos cuenta que la don- 
Proserpina, la todo poderosa hija de Zeus (Júpiter) y de Deméter (Ceres) ${ }^{9}$, gobierna junto a Hades, su esposo, sobre el lóbrego y silencioso mundo de los muertos. Sólo a la sombra del adivino Tiresias, Perséfone le ha permitido conservar la mente despejada y la conciencia: «Tiresias, el adivino ciego, cuya mente todavía está inalterada. Pues sólo a éste, incluso muerto, ha concedido Perséfone tener conciencia» (Odisea, $X, 490)$. Sólo ella hace que se muestren los espectros: «Y se acercaron —pues las impulsaba la ínclita Perséfone - cuantas mujeres eran esposas e hijas de nobles» (Odisea, XI, 226-229).

Hécate, oriunda de la antigua Tracia, diosa de las almas de los muertos, tenía también una significación lunar, por lo que, a veces, ha sido confundida con Ártemis. Hécate, junto con Helio, fue testigo del rapto de Coré por Hades. Según una tradición tardía, Hécate aparece como hija de Zeus (Júpiter) y de Hera (Juno). En cierta ocasión, sufrió la cólera de Hera, a quien robó sus afeites para dárselos a Europa. Hécate huyó, buscando refugio en la casa de una mujer que había dado a luz recientemente, y por este contacto, la diosa quedó impura. Para que la mancha desapareciera, los Cabiros $^{10}$ sumergieron a Hécate en el Aqueronte, con lo que se convirtió en una divinidad infernal. Es, por otra parte, la divinidad de los conjuros espirituales, y especialmente, de los encantamientos. Enviaba a la superficie de la

cella estaba jugando en un prado, cogiendo flores con las hijas de Océano, dios del mar todo abarcador, cuando vio una planta magnífica con cientos de flores que extendían su fragancia por todas partes, que la diosa Tierra (Gea), por orden de Hades, el señor del mundo subterráneo, había enviado expresamente para seducirla. Cuando se dirigió a coger las flores la tierra se abrió y apareció un gran dios en un carro de oro y la llevó al abismo a pesar de sus gritos. El dios era Hades, señor del mundo subterráneo, y en la tierra de los muertos se convirtió en su reina». J. Campbell, Las máscaras de Dios: Mitología primitiva, Alianza, Madrid, 2000, p. 217.

9 Alrededor del 600 a.C., el Himno homérico a Deméter ofreció a los griegos ciertas ideas sobre la muerte y el pasaje al más allá que habían de tener una influencia perdurable. Este himno narra a la vez el mito central de Deméter y Coré y la fundación de los Misterios de Eleusis. Según el mito, Hades quedó prendado de Coré, la hija de Deméter, y la raptó, llevándola a sus dominios. Poseída por el dolor, Deméter buscó a su hija por todas partes. Finalmente, Deméter llamó a Hécate y juntas fueron a visitar a Helios; éste les dice que ha sido designio de Zeus desposar a Coré con Hades. Deméter estaba tan enfadada que no regresó al Olimpo. Con la apariencia de una anciana, llegó a Eleusis, y allí, Deméter, desempeñó el papel de nodriza del hijo recién nacido de la reina Metaneira. En agradecimiento a la hospitalidad que había recibido por parte de la corte de Eleusis, la diosa decidió conceder la inmortalidad a Demofón, el hijo recién nacido de la soberana: lo frotaba con ambrosía, el alimento de los dioses, y por las noches hacía que el fuego del hogar fuese consumiendo la esencia de la mortalidad. Pero una noche Metaneira entró por casualidad en la sala antes de que terminara la operación, y rompió el hechizo. Demofón ya no podía eludir la muerte. Deméter pidió que se le erigiera un templo, donde ella misma enseñaría sus ritos. Una vez construido, la diosa se retiró a su interior, profundamente dolorida por no poder ver a Coré. Infructuosamente, Zeus envió emisarios para pedir a Deméter que regresara al Olimpo. La diosa responde que no volverá jamás junto a los dioses y que no permitirá que salga la vegetación hasta que vea de nuevo a su hija. Entonces Zeus tuvo que llegar a un acuerdo: si Coré no había tomado ningún alimento en el inframundo, tenía que ser devuelta a su madre, pero, si lo había tomado, debía ser la esposa de Hades. Éste, con artimañas, logró introducir en la boca de Coré una pepita de granada, pero esto fue suficiente para asegurarse el retorno anual de Coré durante varios meses junto a él. Una vez recuperada su hija, Deméter accedió regresar al Olimpo y volvió a crecer la vegetación en la tierra. Véase M. Eliade, Historia de las creencias y de las ideas religiosas, Cristiandad, vol. I, Madrid, 1978, pp. 307-310.

10 Deidades arcaicas que simbolizan las fuerzas benéficas de la naturaleza. Su actividad subterránea las subordinó a Hefesto, divinidad del fuego terrestre y las hizo pasar también por deidades infernales. 
tierra a los demonios que son el tormento de los humanos, y subía en persona, por la noche, con su cortejo de perros infernales. Estaba preferentemente en las encrucijadas, junto a las tumbas, o en los parajes que había sido escenario de un crimen. Por eso solía encontrarse su imagen en los cruces de caminos, en forma de columnas o estatuas que representaban a la diosa con tres rostros.

Las Erinias ${ }^{11}$, divinidades ctónicas, nacidas de las gotas de la sangre de Ura$\mathrm{no}^{12}$, tienen la misión de castigar a los parricidas y perjuros. Parece ser que la región donde fueron veneradas primero era Arcadia, donde se adoraba a una Deméter Erinis, su probable ascendiente. Tan pronto como en el ámbito familiar se cometía un crimen - sobre todo cuando un hijo se manchaba con la sangre de sus padres-, aparecían estas negras deidades de mirada torva, con grandes alas desplegadas y pies de bronce, con la cabellera erizada de serpientes y llevando en sus manos antorchas y látigos y se sentaban en el umbral de la casa del asesino, quien trataba en vano de escapar de sus garras. Ni en el Tártaro las Erinias desistían de su labor justiciera.

Con mucha frecuencia el elemento mediante el cual la muerte ha penetrado en el corazón del universo es la mujer ${ }^{13}$, o bien la propia parca es contemplada como una imagen femenina; asimismo hay vírgenes que anuncian la muerte como en el caso de las Sirenas, la Esfinge, Ártemis, Atenea y Pandora ${ }^{14}$. Esta idea, muy difundida en distintos pueblos de la tierra, está ligada a la particular fisiología femenina, que es interpretada como signo de que la mujer está en la frontera entre la «naturaleza» y el reino de las sombras, "un mundo que existe siempre como mundo de los muertos, como mundo antes de la vida y después de la muerte»:

«En toda el área indoeuropea la Diosa Madre está vinculada con la muerte y con el mundo de los muertos. Entre los griegos, Hécate, divinidad del mundo subterráneo o de los Infiernos, reina de los espectros y de las sombras, aparece como una particular manifestación lunar de Ártemis, divinidad funesta y vengativa [...] También Perséfone, la joven del mito de rapto que está en la base de los cultos de Eleusis, es una figura de muerte, instrumento de comunicación, y de paso, con el mundo de los infiernos. Siempre en Grecia, las Erinias, divinidades infernales, son representadas en forma de serpientes, puesto que la serpiente simboliza los

11 El nombre de Euménides («las benévolas») —que sirve de título a una de las tragedias de Esquilo- se ha dado también, algunas veces, a las Erinias. El número de las Erinias se estableció en tres: Tisífone, Mégera y Alecto. Los romanos identificaron a las Erinias con las Furias.

12 «Vino el poderoso Urano conduciendo la noche, se echó sobre la tierra ansioso de amor y se extendió por todas partes. El hijo, saliendo de su escondite, logró alcanzarlo con la mano izquierda, empuñó con la derecha la prodigiosa hoz, enorme y de afilados dientes, y apresuradamente segó los genitales de su padre y luego los arrojó a la ventura por detrás

No en vano escaparon aquéllos de su mano. Pues cuantas gotas de sangre salpicaron, todas las recogió Gea. Y al completarse un año, dio a luz a las poderosas Erinias» (Teogonía, 180-185).

13 «En todas las culturas ha existido, además, una cierta tradición popular de carácter misógino que aparece reflejada en refranes, canciones, fábulas o parodias locales. En este sentido la cultura griega no constituye ninguna excepción a la regla y ofrece la misma gama de motivos dentro de este ámbito». F.J. Gómez Espelosín, Introducción a la Grecia antigua, Alianza, Madrid, 2002, p. 209.

14 Véase Y. Bonnefoy (ed.), Diccionario de las mitologías y de las religiones de las sociedades tradicionales y del mundo antiguo, Destino, vol. II, Barcelona, 1996, pp. 176-177. 
espíritus de la muerte [...] La trinidad de las Moiras, que aparece por primera vez en Hesíodo (Teogonía), dirige el destino del hombre estableciendo el momento de la muerte. El concepto de Moira, como divinidad que teje el hijo de la vida y le pone fin cortándolo, es común también a los romanos y a los germanos (entre los cuales las Moiras aparecen con el nombre de Parcas y de Normas) [...] La conexión entre la muerte y la mujer se hace patente también en el aspecto femenino de la imagen de la muerte, que está presente en muchas áreas culturales [...] La feminidad de la muerte está presente también en la frecuente conexión de la mujer con la Luna y en la bipolaridad luz-tinieblas» ${ }^{15}$.

Otra deidad que ocupa un puesto preeminente en las representaciones de la muerte es el Hermes Nocturno, infernal (ctónico) y por su quehacer de dios de los caminos, es también el psicopompo, el conductor de las almas: «Y Hermes llamaba a las almas de los pretendientes, el Cilenio, y tenía entre sus manos el hermoso caduceo de oro con el que hechiza los ojos de los hombres que quiere y de nuevo los despierta cuando duermen [...] y las conducía Hermes, el Benéfico, por los sombríos senderos» (Odisea, XXIV, 1-10). Guía, mensajero y viajero lo será tanto sobre la tierra como entre los hombres y las tinieblas infernales. Si acompaña a las almas en su viaje por el inframundo, también las trae de regreso a la tierra, como en el caso de Perséfone, Eurídice y Darío.

\section{EL MUNDO DE LOS MUERTOS}

El submundo, el Tártaro ${ }^{16} \mathrm{o}$ el reino de Hades era, según Homero, un lugar bajo tierra de monótona oscuridad lúgubre y triste ${ }^{17}$ : «al tenebroso Tártaro, bien le-

15 Enciclopedia de la filosofía Garzanti, Ediciones B, Barcelona, 1992, p. 688.

${ }^{16}$ Era la región más profunda del Hades, en la que se encontraban los enemigos de las divinidades y los grandes criminales. Allí podía encontrarse a los Cíclopes, los Titanes, los Alóadas y Salmoneo. En Orestes (265) de Eurípides, Orestes teme que las Erinias le arrojen al Tártaro. Para Platón el Tártaro es la morada de los condenados incurables. En el Gorgias (523b), afirma: «Existía en tiempos de Crono, y aun ahora continúa entre los dioses, una ley acerca de los hombres según la cual el que ha pasado la vida justa y piadosamente deber ir, después de muerto, a las Islas de los Bienaventurados y residir allí en la mayor felicidad, libre de todo mal; pero el que ha sido injusto e impío debe ir a la cárcel de la expiación y del castigo, que llaman Tártaro». Posteriormente, este lugar se identificó con los infiernos.

17 En la religión homérica no existe un infierno aterrador como tampoco una existencia plena y afortunada en el mundo celeste. El Elíseo o las Islas de los Bienaventurados, son ámbitos reservados en caso excepcionales para los favoritos de las deidades, como en el caso de Menelao, hermano de Agamenón: «Respecto a ti, Menelao, vástago de Zeus, no está determinado por los dioses que mueras en Argos [...] sino que los inmortales te enviarán a la llanura Elisia [...] Porque tienes por esposa a Helena y para ellos eres yerno de Zeus» (Odisea, IV, 560). La vida del ser humano es la corporeidad y su muerte significa convertirse en una sombra que deambula sin dirección ni propósito y está privada de todo entendimiento. Según H. Thielicke: «la irrepresentabilidad de la muerte se expresa en la religión homérica en situar a los muertos entre dos luces, entre existencia y no existencia, en una situación que, en último término, es incomprensible. La comunicación, que entre los griegos significa un elemento esencial de la existencia humana, está interrumpida entre vivos y muertos. Sin embargo a los muertos no se les ha quitado simplemente su ser; siguen existiendo con una existencia distinta que representa una ruptura de la continuidad con la forma de existencia de los vivientes y, por esto sólo, se puede describir de una manera «mitológica»: existen como sombras en el mundo del Hades». Vivir con la muerte, Herder, Barcelona, 1984, p. 87. 
jos, allí donde se encuentra bajo tierra el más profundo abismo, allí donde las puertas son de hierro y el umbral es de bronce, tan abajo del Hades cuanto el cielo alejado se encuentra de la tierra» (Ilíada, VIII, 10-15); «las moradas mohosas y horrendas que hasta los mismos dioses aborrecen» (Ilíada, XX, 61). Y en Virgilio (70-19 a.C.) leemos:

«A la entrada del Orco, en el vestíbulo, asientan su cubil los vengadores Remordimiento, el Dolor, las pálidas Enfermedades, la Vejez doliente, el Miedo, el Hambre que aconseja crímenes, la Miseria deforme, y, espantables, el Trabajo y la Muerte, con su hermano el Sueño, y las culpables Complacencias del corazón impuro. Al frente habitan la mortífera Guerra, las Euménides en sus lechos de hierro, y la Discordia ciñendo insana las vipéreas crines con sanguinosas vendas. Surge al medio ingente un olmo añoso de anchas ramas, sombrío asiento de los Sueños vanos que al dorso de sus hojas se acurrucan. Mil formas, además, de horrendas fieras: se alojan a la entrada los Centauros, las Escilas biformes, Briareo y el cien brazos, sibilante y torva la Hidra de Lerna, y vomitando llamas la Quimera, las fétidas Harpías, la Gorgona y el monstruo de tres cuerpos» (Eneida, VI, 390420).

En un principio las moradas infernales, Hades o Tártaro, estaban localizadas en el extremo del mundo, después del vasto Oceáno ${ }^{18}$. En la Odisea se narra el periplo de Ulises al «mundo de las sombras» y su invocación a las «almas» de algunos muertos. Circe, la famosa hechicera, indica a Odiseo el lugar donde está situada la morada de Hades: «Cuando hayas atravesado el Océano y llegues a las planas riberas y al bosque de Perséfone -esbeltos álamos negros y estériles cañaverales-, amarra la nave allí mismo, sobre el Océano de profundas corrientes, y dirígete a la espaciosa morada de Hades» (Odisea X, 500-510). En efecto, la tierra habitada se consideraba como una superficie plana limitada por un ancho río de curso circular, el Océano, que era necesario atravesar para llegar a la orilla yerma de las regiones infernales. De superficie árida y desagradable, era imposible que existiera vida alguna, pues el Sol no lo alcanzaba con sus rayos. Crecían allí álamos negros y sauces improductivos, y cubría el suelo el asfódelo, lúgubre planta de ruinas y cementerios. Posteriormente cambió esta visión. La vía de acceso al mundo infernal ya no será el Océano ${ }^{19}$. El mundo infernal comunica con el exterior

18 Océano, «que refluye en sí mismo» (Teogonía, 776); «río perfecto» (Teogonía, 242); «Una décima parte al punto queda apartada; nueve, haciéndolas girar en plateados remolinos por la tierra y los anchos lomos del mar, las precipita en la salada superficie» (Teogonía, 790-791); aparece también como un límite cósmico lindante con el Tártaro: «Delante, apartados de todos los dioses, viven los Titanes al otro lado del tenebroso abismo. Después, los ilustres servidores del muy resonante Zeus habitan palacios sobre las raíces del Océano» (Teogonía, 815); el primero de los grandes cursos de agua que separan a los vivos de los muertos: «Les es difícil a los vivos contemplar esto, pues hay en medio grandes ríos y terribles corrientes, y, antes que nada, Océano, al que no es posible atravesar a pie si no se tiene una fabricada nave» (Odisea, XI, 156-159). Platón sitúa a Océano en un lugar destacado dentro de su sistema de aguas subterráneas: «Hay muchas, grandes y variadas corrientes, pero entre esas muchas destacan cuatro corrientes, de las que aquella con un curso mayor y más extenso que fluye en círculo es el llamado Océano» (Fedón, 112e).

${ }^{19}$ Los griegos situaron el Hades en un más allá que consideraban ya como subterráneo, ya como el límite extremo de los mares, allí donde fluye el río Océano. La primera concepción surge en la Ilíada (XX, 61): «y lanzó un grito, no fuera a ocurrir que Poseidón, el batidor del suelo, por encima la tierra le 
por medio de cavernas profundas y tenebrosas. Asimismo se creía que ciertos ríos conducían a las regiones infernales, como el Aqueronte («corriente de dolor»), cuyo afluente es el Cocito («lamento») $)^{20}$, el cual a su vez, recibe las aguas del Flegetonte («ardiente»), del Lete o Leteo («olvido»)21 y del Estige o Estigia («odiado») $)^{22}$.

Los antiguos nos ofrecen una descripción bastante exhaustiva del aspecto exterior del Hades. Sin embargo, la información sobre el interior es menos precisa. En el instante del óbito el alma abandona el cuerpo y desciende a las moradas infernales, conducida por el dios Hermes. Los griegos tenían la costumbre de poner una moneda en la boca del pariente difunto para pagar a Caronte, el anciano y horrendo barquero, con el fin de que éste cruzara el alma al otro lado del Estigia: «Horrendo el barquero que vela junto al río, Caronte, el viejo horriblemente escuálido: tendida sobre el pecho se enmaraña la luenga barba gris; inmobles miran

hendiera y a la vista quedaran de los mortales y los inmortales las moradas mohosas y horrendas»; «Mas tú ahora a la mansión de Hades te vas, bajo las grutas de la tierra» (Ilíada, XXII,482); «cuanto es apropiado que el muerto tenga cuando se dirige al oscuro poniente, descendiendo» (Ilíada, XXIII,50). Y la segunda en la Odisea $(X, 508)$ : «y cuando hayas atravesado el Océano y llegues a las planas riberas y al bosque de Perséfone -esbeltos álamos negros y estériles cañaverales-, amarra la nave allí mismo, sobre el Océano de profundas corrientes, y dirígete a la espaciosa morada de Hades»; «Entonces llegó nuestra nave a los confines de Océano» (Odisea, $\mathrm{XI}, 13$ ); «Traspusieron las corrientes de Océano y la Roca Leúcade y atravesaron las puertas de Helios y el pueblo de los Sueños; y pronto llegaron a un prado de asfódelo donde habitan las almas, imágenes de los difuntos» (Odisea, XXIV, 11).

20 El Cocito, que a su vez es un brazo de Estigia, se junta con un río de fuego, el Piriflegetonte, para formar el Aqueronte (Odisea, X, 513-515); considerado como un río o una ciénaga que, en la tradición, constituye propiamente la extensión de agua que deben atravesar las almas sobre la barca de Caronte: «Destacan cuatro grandes corrientes, de las que aquella con un curso mayor y más extenso que fluye en círculo es el llamado Océano. Enfrente de él y en sentido opuesto fluye el Aqueronte, que discurre a través de otras y desérticas regiones y, discurriendo bajo tierra, hasta la laguna Aquerusíade, adonde van a parar la mayoría de las almas de los difuntos [...] Un tercer río sale de en medio de éstos, y cerca de su nacimiento desemboca en un terreno amplio que está ardiendo con fuego abundante, y forma una laguna mayor que nuestro mar, hirviente de agua y barro. Desde allí avanza turbulento y cenagoso, y dando vueltas a la tierra llega a otros lugares y a los confines del lago Aquerusíade, sin mezclarse con el agua de éste. Y enroscándose varias veces a la tierra desemboca en la parte de más abajo del Tártaro. Éste es el río que denominan Piriflegetonte [...] Y, a su vez, de enfrente de éste surge el cuarto río [...] el que llaman Estigio, y Estigia llaman a la laguna que forma el río al desembocar allí. Tras haber afluido en ella y haber cobrado tremendas energías en el agua, se sumerge bajo tierra y avanza dando vueltas en un sentido opuesto al Piriflegetonte hasta penetrar en la laguna Aquerusíade por el lado contrario. Tampoco su agua se mezcla con ninguna, sino que avanza serpenteando y desemboca en el Tártaro enfrente del Piriflegetonte. El nombre de este río es, según cuentan los poetas, Cocito [...] Una vez que los difuntos llegan a la región adonde a cada uno le conduce su daímon comienzan por ser juzgados» (Fedón, 113a-d).

21 Para Platón, el alma tiene que beber el agua del río Ameles, en la llanura del Leteo, para que se borre el recuerdo del más allá antes de entrar en un nuevo cuerpo: «Llegada la tarde, acamparon a la orilla del río de la Desatención, cuyas aguas ninguna vasija puede retenerlas. Todas las almas estaban obligadas a beber una medida de agua, pero a algunas no las preservaba su sabiduría de beber más de la medida, y así, tras beber, se olvidaban de todo. Luego se durmieron, y en medio de la noche hubo y trueno y un terremoto, y bruscamente las almas fueron lanzadas desde allí —unas a un lado, otras a otrohacia arriba como estrellas fugaces, para su nacimiento» (República, X, $621 \mathrm{a}-\mathrm{b}$ ).

${ }_{22}$ Río de Arcadia, cerca de la ciudad de Nonacris (Historia, VI, 74), al tiempo que realidad primordial, Estigia, la hija de Océano (Teogonía, 361), aparece en el plano cosmográfico como un brazo de Océano (Teogonía, 789), constituyendo su décimo anillo. La diosa Tetis baña a su hijo Aquiles en el agua de Estigia para hacerlo invulnerable. 
sus ojos, dos centellas; desde el hombro cuelga de un nudo su andrajoso manto. Largo varal empuña, y con la vela hábil maniobra al trasbordar los cuerpos en el mohoso esquife. Ya es anciano, mas su vejez de dios garbea airosa» (Eneida, VI, 425-435). Después de atravesar el Estigia se llega a la puerta del Hades. En ella está el Can cerbero, perro monstruoso de tres cabezas y de ladrido de bronce, preparado para devorar a los intrusos vivientes o a las almas fugitivas: «El sanguinario Cerbero, perro de broncíneo ladrido de Hades, de cincuenta cabezas, despiadado y feroz» (Teogonía, 310).

A su llegada, el alma comparecía ante un tribunal compuesto por Hades y tres jueces ${ }^{23}$ : Minos, Éaco y Radamantis. Según la sentencia que se le imponía, el alma era conducida a las Praderas de Asfódelos, si no son virtuosas ni malas; arrojada al Tártaro, si son malvadas; si son virtuosas eran conducidas a los Campos Elíseos, gobernados por Cronos. En la Eneida (VI, 915-930), Virgilio se refiere al Elíseo como «a unos parajes apacibles llegan, los risueños vergeles que amenizan el Bosque de la dicha, la morada de bienaventuranza y paz. Más amplio el éter aquí los campos de una lumbre vista de purpúreo esplendor; aquí contemplan su propio sol y sus estrellas propias. Atletas unos se ejercitan ágiles en palestras de grama, ya jugando, ya en noble lucha en la rojiza arena. Otras la tierra pulsan en la danza y cantan sus canciones. Las responde el tracio sacerdote de talares augustas vestiduras con la lira de siete voces cónsonas, pulsada con los dedos o el plectro marfilino». Muy cerca están las Islas de los Bienaventurados, reservadas para aquellos que han nacido tres veces y han alcanzado tres veces el Elíseo. Cualquier alma de los Campos Elíseos puede reencarnar y regresar a la tierra tres veces. No obstante, antes de marcharse, el alma debe beber el agua del Leteo: «Mas estas almas que estás viendo, todas, completado ya el ciclo de mil años, llamadas por un dios, van al Lete o Leteo en muchedumbre inmensa, porque puedan a la región terrestre sin memoria volver un día, y el deseo cobren de tornar a los cuerpos" (Eneida, VI, 1080-1085). Aquí el gran poeta latino adoptó un punto de vista pitagórico en cuanto a la condición de los muertos.

En un tono satírico, Luciano de Samosata (125-192) relata su descenso al Hades a consultar con el alma del adivino Tiresias y el regreso al mundo de los vivos para referir todo lo que vio:

«Ya se iba distinguiendo cada lugar con claridad; la laguna, el Piriflegetonte y los reinos de Plutón. Descendiendo por la grieta, encontramos a Radamantis, que por poco si se muere de miedo. Cerbero dio un ladrido y se movió, pero, al tocar yo la lira y oír el canto, se amansó instantáneamente. Una vez que llegamos a las inmediaciones de la laguna, por poco no conseguimos que nos pasaran al otro lado. La barca estaba ya hasta los topes, llena de gemidos y todos navegaban con algún tipo de lesión [...] No obstante, el excelente Caronte, cuando vio la piel de león, creyéndose que yo era Heracles, nos acogió en la barca, gustoso nos pasó a la otra orilla y nos indicó, claramente, el sendero que debíamos tomar al desembarcar [...] llegamos a un prado enorme cuajado de asfódelos, donde las sombras

${ }^{23}$ El primer testimonio de que disponemos, en cuanto a la creencia en un juicio de los muertos y su traslado a las moradas infernales o a las paradisíacas según la sentencia, procede de Egipto. 
de los muertos chirriantes revoloteaban a nuestro alrededor. Avanzamos paso a paso y nos detuvimos en las cercanías del tribunal de Minos. Casualmente se encontraba sentado en un trono elevado, flanqueado por los Tormentos, las Erinis y las Venganzas. De uno y otro lado le iban trayendo a su presencia remesas de gentes unos tras otros, encadenados a una gruesa maroma [...] Aparte, los hombres de dinero y prestamistas se acercaban pálidos, barrigudos y achacosos de gota, oprimido cada uno de ellos por una gruesa cadena al cuello y una pesada bola [...] Minos, examinando escrupulosamente caso por caso, iba enviando a cada uno al lugar de los impíos, a pagar sus culpas, en proporción a las fechorías cometidas; y dedicaban mayor atención a las de aquellos que se habían visto ofuscados por la riqueza y los cargos públicos [...] Retirándonos del tribunal, llegamos al lugar de los tormentos. Allí, amigo, había muchas situaciones cuya contemplación o relato moverían a compasión. Se escuchaba el chasquido de los azotes, el lamento de quienes eran consumidos en la pira; había aparatos para estirar y retorcer los miembros y ruedas de tormentos [...] También vi lo que se cuenta en los mitos, a Ixión, a Sísifo y al frigio Tántalo; lo pasaban francamente mal; y al hijo de la tierra, a Titión [...] Algunos, por ignorancia, se molestan y se enfadan, cuando el Destino reclama su atavío, como si se vieran privados de algo suyo propio, cuando no hacen sino devolver algo que se les prestó por un corto espacio de tiempo [...] Pero creo que aún te reirías mucho más, si hubieras visto a quienes entre nosotros son reyes y sátrapas, mendigando allí y vendiendo productos para embalsamar momias, por no tener recursos, o enseñando las primeras letras, y humillados por el primero que les sale al paso y golpeados en la mejilla, en situaciones como las más deshonrosas de los esclavos [...] Sócrates anda por allí también dando vueltas poniendo a todos en la picota [...] De resultas de haber bebido el veneno aún tenía las piernas más gordas de lo normal e hinchadas [...] Yo volví al objetivo que me había llevado allí: ver a Tiresias [...] Él, apartándome y conduciéndome lejos de los demás, acercándoseme al oído me dice en voz baja: «la vida más excelente y sensata es la de los hombres de a pie [...] te afanarás en conseguir llana y simplemente el siguiente objetivo: dedicarte a vivir de buena forma el presente riéndote de la mayoría de las cosas y sin tomar nada en serio» (Menipo o la necromancia, 10-22).

La mitología griega describía figuras arquetípicas que experimentaban un sufrimiento eterno de proporciones realmente heroicas por sus insolencias y ultrajes a las divinidades. Aquellos que habían insultado a Zeus eran confinados en el pozo sin fondo del Tártaro y padecían todo tipo de tormentos ${ }^{24}$ : tal es el caso de Sísifo²5,

${ }^{24}$ En la Metamorfosis (IV, 445-640), Ovidio nos ofrece la siguiente narración: «La Saturnia Juno resuelve ir allí tras dejar su morada celestial (tanto concedía a sus odios y a su ira). Tan pronto como entró y rechinó el umbral con la presión del sagrado cuerpo, Cérbero levantó sus tres bocas lanzando tres ladridos al mismo tiempo. Juno llamó a las hermanas nacidas de la Noche, deidades duras e implacables. Estaban sentadas ante las puertas de la cárcel cerradas con acero y en lugar de sus cabellos peinaban negras serpientes. Tan pronto como la reconocieron entre las sombras oscuras, se levantaron las diosas. Se llama la Morada Criminal. Titio ofrecía sus entrañas para que se las despedazasen tendido como estaba a lo largo de nueve yugadas; para ti, Tántalo, ningún agua se coge y huye el árbol que asoma a tu cabeza; o buscas o empujas, Sísifo, la roca que ha de volver; Ixión da vueltas persiguiéndose y huyendo de sí mismo; y por atreverse a maquinar la muerte de sus primos las Bélidas buscan continuamente el agua que han perdido».

${ }_{25}$ Una interesante interpretación de este figura arquetípica se halla en El Mito de Sísifo de Albert Camus: «Los dioses habían condenado a Sísifo a subir sin cesar una roca hasta la cima de una montaña desde donde la piedra volvía a caer por su propio peso. Habían pensado con alguno fundamento que no hay castigo más terrible que el trabajo inútil y sin esperanza. 
hijo de Eolo. Zeus ordenó a Hades que llevase a Sísifo al Tártaro y le castigase eternamente por haber revelado los secretos divinos. Para escapar de Hades, Sísifo lo encadenó, utilizando el engaño. La siguiente treta para evitar el Tártaro con-

Si se ha de creer a Homero, Sísifo era el más sabio y prudente de los mortales. No obstante, según otra tradición, se inclinaba al oficio de bandido. No veo en ello contradicción. Difieren las opiniones sobre los motivos que le llevaron a convertirse en el trabajador inútil de los infiernos. Se le reprocha, ante todo, alguna ligereza con los dioses. Reveló los secretos de éstos. Egina, hija de Asopo, fue raptada por Júpiter. Al padre le asombró esa desaparición y se quejó a Sísifo. Éste, que conocía el rapto, se ofreció a informar sobre él a Asopo con la condición de que diese agua a la ciudadela de Corinto. Prefirió la bendición del agua a los rayos celestiales. Por ello le castigaron enviándole al infierno. Homero nos cuenta también que Sísifo había encadenado a la Muerte. Plutón no pudo soportar el espectáculo de su imperio desierto y silencioso. Envió al dios de la guerra, quien liberó a la Muerte de las manos de su vencedor.

Se dice también que Sísifo, cuando estaba a punto de morir, quiso imprudentemente poner a prueba el amor de su esposa. Le ordenó que arrojara su cuerpo insepulto en medio de la plaza pública. Sísifo se encontró en los infiernos y allí, irritado por una obediencia tan contraria al amor humano, obtuvo de Plutón el permiso para volver a la tierra con objeto de castigar a su esposa. Pero cuando volvió a ver el rostro de este mundo, a gustar del agua y del sol, de las piedras cálidas y del mar, ya no quiso volver a la oscuridad infernal. Los llamamientos, las iras y las advertencias no sirvieron de nada. Vivió muchos años más ante la curva del golfo, la mar brillante y las sonrisas de la tierra. Fue necesario un decreto de los dioses. Mercurio bajó a la tierra a coger al audaz por el cuello, le apartó de sus goces y le llevó por la fuerza a los infiernos, donde estaba ya preparada su roca.

Se ha comprendido ya que Sísifo es el héroe absurdo. Lo es tanto por sus pasiones como por su tormento. Su desprecio de los dioses, su odio a la muerte y su apasionamiento por la vida le valieron ese suplicio indecible en el que todo el ser se dedica a no acabar nada. Es el precio que hay que pagar por las pasiones de esta tierra. No se nos dice nada sobre Sísifo en los infiernos. Los mitos están hechos para que la imaginación los anime. Con respecto a éste, lo único que se ve es todo el esfuerzo de un cuerpo tenso para levantar la enorme piedra, hacerla rodar y ayudarla a subir una pendiente cien veces recorrida; se ve el rostro crispado, la mejilla pegada a la piedra, la ayuda de un hombro que recibe la masa cubierta de arcilla, de un pie que la calza, la tensión de los brazos, la seguridad enteramente humana de dos manos llenas de tierra. Al final de ese largo esfuerzo, medido por el espacio sin cielo y el tiempo sin profundidad, se alcanza la meta. Sísifo ve entonces cómo la piedra desciende en algunos instantes hacia ese mundo inferior desde el que habrá de volver a subirla hasta las cimas, y baja de nuevo a la llanura.

Sísifo me interesa durante ese regreso, esa pausa. Un rostro que sufre tan cerca de las piedras es ya él mismo piedra. Veo a ese hombre volver a bajar con paso lento pero igual hacia el tormento cuyo fin no conocerá jamás. Esta hora que es como una respiración y que vuelve tan seguramente como su desdicha, es la hora de la conciencia. En cada uno de los instantes en que abandona las cimas y se hunde poco a poco en las guaridas de los dioses, es superior a su destino. Es más fuerte que su roca.

$\mathrm{Si}$ este mito es trágico, lo es porque su protagonista tiene conciencia. ¿En qué consistiría, en efecto, su castigo si a cada paso le sostuviera la esperanza de conseguir su propósito? [...] Sísifo, proletario de los dioses, impotente y rebelde, conoce toda la magnitud de su miserable condición: en ella piensa durante su descenso. La clarividencia que debía constituir su tormento consuma al mismo tiempo su victoria. No hay destino que no se venza con el desprecio.

Por lo tanto, si el descenso se hace algunos días con dolor, puede hacerse también con alegría. Esta palabra no está de más. Sigo imaginándome a Sísifo volviendo hacia su roca, y el dolor estaba al comienzo. Cuando las imágenes de la tierra se aferran demasiado fuertemente al recuerdo, cuando el llamamiento de la felicidad se hace demasiado apremiante, sucede que la tristeza surge en el corazón del hombre: es la victoria de la roca, la roca misma. La inmensa angustia es demasiada pesada para poder sobrellevarla [...] Su destino le pertenece. Su roca es su cosa. Del mismo modo, el hombre absurdo, cuando contempla su tormento, hace callar a todos los ídolos. En el universo súbitamente devuelto a su silencio se elevan las mis vocecillas maravilladas de la tierra. Llamamientos inconscientes y secretos, invitaciones de todos los rostros constituyen el reverso necesario y el premio de la victoria. No hay sol ni sombra y es necesario conocer la noche. El hombre absurdo dice «sí» y su esfuerzo no terminará nunca. Si hay un destino personal, no hay un destino superior, o, por lo menos, no hay más que uno al que juzga fatal y despreciable. Por lo demás, sabe que es dueño de sus días. En ese instante sutil en que el hombre vuelve sobre su vida, como Sísifo vuelve hacia su roca, en ese ligero giro, contempla esa serie 
sistió en incumplir la promesa hecha a Perséfone. Hubo que llamar a Hermes para que condujese a Sísifo de vuelta por la fuerza a su destino final: el reino de Hades. Y allí recibió un castigo ejemplar: fue obligado a hacer rodar una pesada roca hasta la cumbre de una montaña: «Y ví a Sísifo, que soportaba pesados dolores, llevando una enorme piedra entre sus brazos. Hacía fuerza apoyándose con manos y pies y empujaba la piedra hacia arriba, hacia la cumbre, pero cuando iba a trasponer la cresta, una poderosa fuerza le hacía volver una y otra vez y rodaba hacia la llanura la desvergonzada piedra. Sin embargo, él la empujaba de nuevo con los músculos en tensión y el sudor se deslizaba por sus miembros y el polvo caía de su cabeza» (Odisea, XI, 590).

Tántalo ${ }^{26}$, rey de Lidia o de Frigia, amigo íntimo de Zeus, robó el néctar y la ambrosía de la mesa de los dioses del Olimpo para compartirlos con sus amigos mortales. Antes de que se descubriera esta acción hizo algo peor: sirvió a los dioses el cuerpo desmembrado de su hijo Pélope. Por estas ofensas, Tántalo fue castigado con el tormento eterno en compañía de Sísifo, Ticio, Ixión y otros. Homero describe a Tántalo padeciendo una sed y un hambre espantosas, aún más terribles por estar sumergido en un estanque con el agua hasta la barbilla y rodeado de las más apetitosas viandas: cuando abre la boca para beber agua y consumir el alimento, las aguas retroceden y los manjares desaparecen quedando fuera de su alcance $^{27}$ : «También vi a Tántalo, que soportaba pesados dolores, en pie dentro del lago; éste llegaba a su mentón, pero se le veía siempre sediento y no podía tomar agua para beber, pues cuantas veces se inclinaba el anciano para hacerlo, otras tantas desaparecía el agua absorbida y a sus pies aparecía negra la tierra, pues una divinidad la secaba. También había altos árboles que dejaban caer su fruto desde lo alto - perales, manzanos de hermoso fruto, dulces higueras y verdeantes olivos-, pero cuando el anciano intentaba asirlas con sus manos, el viento las impulsaba hacia las oscuras nubes» (Odisea, XI, 580-590). Al suplicio anterior hay que añadir otro: una gigantesca piedra, un gran risco del monte Sípilo, sobresale por encima del árbol y amenaza eternamente con aplastar el cráneo de Tántalo. Según Platón: «A las muchas y terribles desventuras que le sobrevinieron en vida, cuyo colmo fue la ruina de toda su patria y, una vez muerto, la piedra tan

de actos desvinculados que se convierte en su destino, creado por él, unido bajo la mirada de su memoria y pronto sellado por su muerte. Así, persuadido del origen enteramente humano de todo lo que es humano, ciego que desea ver y que sabe que la noche no tiene fin, está siempre en marcha. La roca sigue rodando.

Dejo a Sísifo al pie de la montaña. Se vuelve a encontrar siempre su carga. Pero Sísifo enseña la fidelidad superior que niega a los dioses y levanta las rocas. Él también juzga que todo está bien. Este universo en adelante sin amo no le parece estéril ni fútil. Cada uno de los granos de esta piedra, cada fragmento mineral de esta montaña llena de oscuridad, forma por sí solo un mundo. El esfuerzo mismo para llegar a las cimas basta para llenar un corazón de hombre. Hay que imaginarse a Sísifo dichoso». A. Camus, El mito de Sísifo, Alianza, Madrid, 1996, pp. 167-173.

${ }^{26}$ El origen y la ascendencia de Tántalo no están claros: «Su madre era Pluto, hija de Cronos y Rea, o, según dicen algunos, de Océano y Tetis; y su padre Zeus o Tmolo». R. Graves, Los mitos griegos, Alianza, vol. 2, Madrid, 1985, pp. 27-28.

${ }_{27}$ Véase Ovidio, Metamorfosis, 455; Píndaro, Olímpicas, I, 54-65; Luciano, Diálogo de los muertos, 7(17). 
acorde con su nombre, «que gravita» (talanteía) sobre su cabeza en el Hades» (Crátilo, 395 d-e).

El gigante Ticio intentó violar a Leto, mientras ésta oraba en una cueva sagrada. Cuando Apolo y Ártemis oyeron los gritos de Leto, corrieron y mataron a Ticio con una descarga de flechas. Ya en el Tártaro atormentaron al gigante extendiéndolo con los brazos y las piernas sujetos a la tierra y dos buitres le devoraban el hígado: «Y vi a Ticio, al hijo de la Tierra augusta, yaciendo en el suelo. Estaba tendido a lo largo de nueve yugadas, y dos águilas posadas a sus costados le roían el hígado, penetrando en sus entrañas. Pero él no conseguía apartarlas con sus manos, pues había violado a Leto, esposa augusta de Zeus, cuando ésta se dirigía a Pito a través del hermoso Panopeo» (Odisea, XI, 580).

El osado Ixión, héroe tesalio, hijo de Flegias, el rey lapita, intentó seducir a Hera, esposa de Zeus. Pero este último adivinó sus planes y ordenó a Hermes que lo flagelase sin compasión, y luego lo ató a una rueda ardiendo, que giraba sin parar por los aires:

«|xión, hijo de Flegias, el rey lapita, convino en casarse con Día, hija de Deyoneo, le prometió ricos regalos de boda e invitó a Deyoneo a un banquete, pero preparó delante del palacio una trampa con un gran fuego de carbón vegetal debajo, y el confiado Deyoneo cayó en ella y se quemó.

Aunque los dioses menos importantes lo consideraron una acción nefanda y se negaron a purificar a Ixión, Zeus, que obraba igualmente mal cuando se enamoraba, no sólo le purificó, sino que además lo llevó a comer en su mesa.

Ixión era desagradecido y se propuso seducir a Hera [...] Pero Zeus adivinó las intenciones de Ixión y dio a una nube la forma de una falsa Hera con la que Ixión, que había bebido demasiado para descubrir el engaño, satisfizo su deseo. Zeus le sorprendió in fraganti y ordenó a Hermes que lo azotase sin piedad hasta que repitiese las palabras: «Los benefactores merecen ser honrados», y luego lo ató a una rueda ardiente que gira sin cesar por el firmamento ${ }^{28}$.

Prometeo, el más célebre de los titanes y esposo de Pandora, robó el fuego a Zeus y lo entregó a los hombres junto con el conocimiento de la artesanía y la tecnología y fue encadenado a una roca en las montañas del Cáucaso y atacado periódicamente por un buitre, que picoteaba sus entrañas ${ }^{29}$ :

«Prometeo engañó a Zeus y dividió un buey en dos pilas. En una colocó la carne y las entrañas y las cubrió con el vientre del animal, de forma que Zeus pensara que ese montón era de desperdicios y se lo devolviera a Prometeo. En la otra pila, Prometeo puso los huesos y colocó la grasa encima. Cuando Prometeo le ofreció las dos pilas a Zeus, el dios naturalmente escogió la que tenía la grasa encima. Pero cuando Zeus se dio cuenta de que había sido engañado, dijo, "iQué Prometeo y los humanos coman la carne cruda; nunca les permitiré que tengan el fuego!».

28 R. Graves, Los mitos griegos, Alianza, vol. 1, Madrid, 1985, p. 257.

29 La narración más antigua sobre Prometeo se encuentra en la Teogonía (521-616) de Hesíodo. 
Prometeo sabía que los mortales necesitarían del fuego para que se desarrollara la civilización, ya que la comida, la cerámica y la metalistería necesitan de él. Así que Prometeo fue a ver a Atenea, la diosa de la sabiduría, para que, de manera ostensible, intercediera por él. Sin embargo, nunca llegó a hablar con ella. Se introdujo en el palacio de los dioses por la puerta trasera y cuando llegó al carro del sol, robó un poco de su fuego y lo ocultó en un tallo hueco de hinojo. Entonces volvió y dio el fuego a la Humanidad, violando directamente la orden de Zeus.

Cuando Zeus descubrió el robo se puso furioso. Antes del hurto, sólo había humanos varones, de modo que Zeus ordenó a Hefesto, el dios de la metalurgia y artesano de los dioses, que hiciera una mujer humana de barro. Modeló, pues, una bella mujer y Afrodita la dotó de más belleza y encanto. Atenea le dio las habilidades para cocinar, tejer e hilar y otros dioses y diosas le otorgaron aún más dones. De esta forma, fue llamada Pandora, que significa «bien dotada».

La intención de Zeus era dar a Pandora a Prometeo como «regalo». Como un presente adicional, los dioses le dieron a ella una caja de barro sellada. Prometeo advirtió a su hermano Epimeteo que no aceptara los regalos, pero Epimeteo ni hizo caso. Zeus castigó a Prometeo por avisarle a su hermano haciéndolo encadenar a una roca en el Caúcaso, donde un buitre lo atacaba constantemente causándole heridas en el hígado» ${ }^{30}$.

\section{TRANSMIGRACIÓN E INMORTALIDAD}

La forma de afrontar las incógnitas y disipar los temores acerca de la muerte ha generado a lo largo de la historia el desarrollo de diversas concepciones escatológicas que, si bien han variado con el transcurso de los siglos y según las distintas culturas, al final se redujeron a dos grandes ideas que aún vertebran las más importantes filosofías religiosas del planeta: la doctrina de la transmigración ${ }^{31}$ y la creencia en la inmortalidad.

El deseo de continuar viviendo después de la muerte, de una «segunda oportunidad», es sin duda un anhelo humano que para un sector de la humanidad se satisface mediante la creencia en la transmigración. Vivir no solamente una vez, sino poseer un bagaje de experiencias de vidas anteriores y tener ante sí la posibilidad de posteriores existencias, he aquí un tipo de esperanza que cautiva a muchos. Filósofos, escritores y poetas del mundo clásico han abrazado esta teoría.

30 J.F. Bierlein, El espejo eterno. Mitos paralelos en la historia del hombre, Oberón, Madrid, 2001, pp. $129-130$.

31 Palabra derivada del griego, que significa: «paso del alma de un cuerpo a otro»; esta idea se expresa también con otros términos como «metensomatosis», "palingenesia», «transmigración», «reencarnación», «metangismosis» o «renacimiento»: «o bien de manera que se afirma la inmediata reencarnación humana (Platón, antroposofía), o bien de modo que el destino óntico del alma como parte inmortal del hombre incluye diversos estados intermedios entre distintas encarnaciones (órficos, mito platónico, budismo, etc.), pudiendo producirse tales estados intermedios bajo forma de encarnaciones en otros seres vivos o inteligencias (quizá Orígenes, neopitagóricos, budistas e hinduistas). Además el proceso de palingenesia se piensa como ilimitado en dirección al pasado y (o) al futuro (pitagóricos, algunos gnósticos, hinduismo, budismo), o como caminando a una conclusión definitiva (doctrina cristiana de la apocatástasis, Zoroastro, antroposofía)". VV.AA., Conceptos fundamentales de filosofía, Herder, Barcelona, 1978, p. 591. 
En el mundo griego, la doctrina de la transmigración formaba parte del entramado doctrinal del orfismo ${ }^{32}$, para el cual la liberación del ser humano residía en la interrupción de las existencias: «En castigo de un crimen primordial, el alma es encerrada en el cuerpo (sôma) como si fuera un sepulcro (sêma). En consecuencia, la existencia encarnada se parece más bien a una muerte, mientras que la muerte constituye el comienzo de la verdadera vida. Sin embargo, esta «vida verdadera» no se obtiene automáticamente; el alma es juzgada conforme a sus méritos o sus faltas, y pasado algún tiempo se encarna de nuevo. Al igual que en la India a partir de las Upanishads, se trata de la creencia en la indestructibilidad del alma, condenada a transmigrar hacia su liberación final» ${ }^{33}$.

La idea de los griegos sobre la transmigración, quizá derivada de sus contactos con la India ${ }^{34}$, estaba ya bastante arraigada varios siglos antes del nacimiento de Cristo: «Es muy improbable que tenga su origen en el suelo griego y muy verosímil que proceda de Oriente, siendo la India, como ya dijimos, el lugar que con más posibilidades cuenta» ${ }^{35}$. Parece cierto, si algo cierto se puede saber sobre la filosofía de Pitágoras (c. 572-497 a.C.), que este sabio de la Grecia antigua defendió la doctrina de la transmigración. Jenófanes de Colofón (c. 540-480 a.C.), contemporáneo de Pitágoras, se burlaba del célebre filósofo de Samos. En efecto, en Vida de Pitágoras, Diógenes Laercio nos habla de un poema de Jenófanes en

32 Corriente místico-religiosa difundida en Grecia a partir del siglo vı a.C. fundada por Orfeo. Véase E. Rohde, Psique (el culto de las almas y la creencia en la inmortalidad entre los griegos), Ágora, Málaga, 1995 , pp. 479-500.

${ }_{33}$ M. Eliade, Historia de las creencias y de las ideas religiosas, Cristiandad, vol. II, Madrid, 1979, p. 188.

${ }^{34}$ La semejanza entre la teoría de la transmigración hindú y budista y la de los órfico-pitagóricos es tan estrecha que es bastante improbable que sea casual: «Las dos ubicaciones de dicha creencia son geográficamente remotas, y alrededor del 500 a.C. los medios de comunicación entre ambas eran escasos. Acaso uno de los conductores haya sido el Primer Imperio Persa, pues, hacia esta fecha, ese imperio incluía tanto la franja occidental del subcontinente indio como la franja oriental del mundo griego contemporáneo, incluida la isla de Samos, cuna y hogar de Pitágoras antes de su migración a la ciudadestado Crotona, en las colonias griegas del sur de Italia. El gobierno imperial persa tomó, en sus inicios, algunas medidas para mejorar el sistema de comunicaciones. Construyó carreteras de troncos cada tanto equipadas con caballos de refresco, y abrió canales de agua que comunicaban el Indo y sus tributarios con el Bajo Nilo, vía el océano Índico y el Mar Rojo.

De todos modos, quizá sea lo más probable que la doctrina de la reencarnación haya llegado tanto sudoeste de Europa cuanto a la India a través de una Völkerwanderung de pastores nómadas que, en los siglos VIII y VII a.C. irrumpieron desde la estepa de Eurasia en la cuenca del Indo, dirigiéndose al sudeste, y desde Tracia, dirigiéndose hacia el sudoeste [...] El historiador griego Herodoto, en el siglo v a.C., nos refiere que Aristeas - ciudadano de la ciudad-estado colonial proconeso, en la costa asiática del Mar de Mármara, que había visitado la estepa de Eurasia y había escrito un poema sobre sus habitantes nómades- desapareció y reapareció dos veces y que, mucho después de sus segunda desaparición, reapareció no en su ciudad natal, sino en otra distante ciudad-estado de las colonias griegas, Metaponto, en la costa del Sudeste de Italia. Herodoto refiere además la historia de Zalmoxis, espíritu honrado por los getas, pueblo nómade de Eurasia [...] De acuerdo con esta historia, Zalmoxis, originalmente había sido un esclavo humano y un discípulo de Pitágoras en Samos, y después se las había compuesto para que la gente de su tribu, los getas, creyeran que él había muerto y resucitado a los cuatro años». A.J. Toynbee, «El interés del hombre en la vida después de la muerte», en VV.AA., La vida después de la muerte, EDHASA, Barcelona, 1985, pp. 32-33.

35 K. Prümm, «La religión de los griegos», en F. König, Cristo y las religiones de la tierra, Biblioteca de Autores Cristianos, vol. II, Madrid, 1960, p. 119. 
que éste cuenta que Pitágoras: «hallándose presente cierta vez que a un perrito castigaban, se refiere que dijo: «Cesa de apalearlo, que es el alma de un amigo; en el eco lo conozco» »36. Por su parte, Heráclides Póntico (s. IV a.C.), discípulo de Platón, afirma que Pitágoras decía de sí mismo que «»en otro tiempo había sido Etálides [...] después Euforbo, luego Hermótimo y en seguida Pirro». Y finalmente, que después de muerto Pirro vino a ser Pitágoras, y se acordaba de todo cuanto hemos mencionado»37. Según J. Crehan:

«Tales teorías suponen una separación del cuerpo y del alma en el instante de morir, separación a la que alude el famoso monumento a los atenienses caídos en Potidea en el 432 a.C.: «El éter acogió las almas, la tierra, los cuerpos de quienes cayeron ante las puertas de Potidea». La frase «el cuerpo es el manto del alma» constituía, al parecer, un principio de la escuela pitagórica, y por esa razón a Perséfone se la representaba afanándose ante el telar, tejiendo nuevos cuerpos para las viejas almas. Hay Lamellae de oro (de Petelia, Farsalia y Creta) que dan indicaciones al alma para cuando ésta abandone el cuerpo: «Hallarás un arroyo a la izquierda, en el Hades, y junto a él un criprés blanco...» Se le indicaba al alma que pidiera el agua de la rememoración de dicho arroyo, que presumiblemente le garantizaría la evocación de su vida anterior en su próxima existencia»38.

Por su parte, Empédocles de Agrigento (s. V a.C.) poseía el recuerdo más completo de sus encarnaciones pasadas que incluían: «muchacho y muchacha, y un arbusto y un pájaro y un pez escamoso en el mar»39.

Píndaro de Tebas (522-448 a.C.) hace alusión a la idea de la transmigración ${ }^{40}$ de este modo: «Y aquellos que, por tres veces, han vivido a ambos lados y el valor han tenido de conservar sin mancha de injusticia sus almas» (Epinicios, 70).

Platón sostiene que algunas almas pueden mejorar después de la muerte y se encarnan de nuevo. En uno de sus célebres Diálogos, el gran filósofo griego pone

36 D. Laercio, Vidas de filósofos ilustres, Iberia, Barcelona, 2000, p. 306.

37 Ibíd., p. 316.

38 J. Crehan, «Las sociedades del Cercano Oriente», en VV.AA., ob.cit., p. 127.

39 C. García Gual (ed.), Antología de la poesía lírica griega (siglos VII-IV A.C.), Alianza, Madrid, 2001, pp. 66-67.

40 En su introducción a Olímpicas de Píndaro, M. Fernández-Galiano se refiere a la transmigración así: «Se trata de la creencia en sucesivas reencarnaciones y purificaciones de las almas basadas siempre en el premio del bien y castigo del mal. La idea no resulta del todo clara por la oscuridad deliberada en que encubre el poeta su pensamiento y por falta del contexto correspondiente a los fragmentos citados, pero parece que es la siguiente: El alma inmortal, de origen divino, lleva consigo una «antigua culpa», una especie de pecado original, para expirar el cual tiene que permanecer encadenada al cuerpo mortal del hombre. Al morir, éste es juzgado en el Hades: si su conducta ha sido irreprochable y, por tanto, es absuelto, pasa a una existencia sin pena ni gloria, una especie de limbo, mientras los malos (por ejemplo, Tántalo) son condenados a una pena [...] Aunque no lo dice, da a entender el poeta que todos ellos, buenos y malos, vuelven a la vida después de un determinado espacio de tiempo; sin embargo, se desentiende de la suerte de los impíos [...] Respecto a los piadosos, entre los que se cuenta Terón, se van purificando de la antigua culpa mediante estancias alternativas expiatorias en la tierra -en distintos cuerpos - y el Hades — en el limbo de que hemos hablado- hasta completar tres vidas terrenas con sus correspondientes tres periodos de purificación en el otro mundo». Consejo Superior de Investigaciones Científicas, Madrid, 1956, p. 132. 
en boca de Er, un guerrero que consiguió volver del reino de los muertos y contar sus experiencias, lo siguiente:

«Tal — decía- era aquel interesante espectáculo en que las almas, una por una, escogían sus vidas; el cual, al mismo tiempo, resultaba lastimoso, ridículo y extraño, porque la mayor parte de las veces se hacía la elección según aquello a lo que se estaba habituado en la vida anterior. Y dijo que había visto allí cómo el alma que en un tiempo había sido de Orfeo elegía vida de cisne [...] había visto también al alma de Támiras, que escogía vida de ruiseñor [...] El alma a quien había tocado el lote veinteno había elegido vida de león, y era la de Ayante Telamonio, que rehusaba volver a ser hombre, acordándose del juicio de las almas. La siguiente era la de Agamenón, la cual, odiando también, a causa de sus padecimientos, al linaje humano, había tomado en el cambio una vida de águila [...] Después de ésta vio el alma de Epeo, hijo de Panopeo, que trocó su condición por la de una mujer laboriosa; y, ya entre las últimas, a la del ridículo Tersites, que revistió forma de mono [...] De igual manera se hacía transformaciones de los animales en hombres o en otros animales: los animales injustos se cambiaban en fieras; los justos, en animales mansos, y se daban también mezclas de toda clase» (República, $\mathrm{X}$, 620a-620d).

Platón intentó aplicar cierto orden a la doctrina de la metempsicosis. El alma, al comienzo de su existencia, intenta elevarse por las esferas hasta que contempla con claridad las verdades celestiales. Pero si pierde las alas, se desploma hasta caer en un cuerpo sólido en el que queda apresada: «Cualquier alma que, en el séquito de lo divino, haya vislumbrado algo de lo verdadero, estará indemne hasta el próximo giro y, siempre que haga lo mismo, estará libre de daño. Pero cuando, por no haber podido seguirlo, no lo ha visto, y por cualquier azaroso suceso se va gravitando llena de olvido y dejadez, debido a este lastre, pierde las alas y cae a tierra.

Entonces es de ley que tal alma no se implante en ninguna naturaleza animal, en la primera generación, sino que sea la que más ha visto la que llegue a los genes de un varón que habrá de ser amigo del saber, de la belleza o de las Musas» (Fedro, 248c-d).

También en el Menón, Platón se refiere a la transmigración: «El alma, pues, siendo inmortal y habiendo nacido muchas veces, y visto efectivamente todas las cosas, tanto las de aquí como las del Hades, no hay nada que no haya aprendido" (Menón, 81c).

Platón nos cuenta en uno de sus célebres Diálogos las experiencias vividas por un guerrero, de nombre Er que consiguió regresar del país de los muertos. La narración comienza con una feroz batalla en la que muere Er. Sus compañeros lo trasladan hasta su pueblo, donde va a tener lugar la ceremonia de cremación de su cuerpo. Pero estando ya todo dispuesto, Er comenzó a dar señales de vida. Al cabo de un tiempo, su cuerpo revivió y Er describe lo que vio en el viaje al mundo de ultratumba. En primer lugar, su alma salió del cuerpo, se unió a otras almas y todas llegaron a un lugar en el que había dos aberturas "que comunicaban entre sí y otras dos arriba en el cielo, frente a ellas» (República, 614c); las almas que llegaban de la tierra, una vez juzgadas, iban ya hacia la derecha, ya hacia la izquierda: «En mitad había unos jueces que, una vez pronunciados sus juicios, 
mandaban a los justos que fueran subiendo a través del cielo, por el camino de la derecha, tras haberles colgado por delante un rótulo con lo juzgado; y a los injustos les ordenaba ir hacia abajo por el camino de la izquierda, llevando también, éstos detrás, la señal de todo lo que habían hecho" (República, 614c y d). Sin embargo, Er no fue juzgado. Los jueces le dijeron que debía regresar para informar a los hombres acerca de cómo era el mundo de ultratumba y le invitaron a que escuchara y viera lo que acontecía en aquel lugar: «y así vio cómo, por una de las aberturas del cielo y otra de la tierra, se marchaban las almas después de juzgadas; y cómo, por una de las otras dos, salían de la tierra llenas de suciedad y de polvo [...] y se hacían mutuamente sus relatos, las unas entre gemidos y llantos, recordando cuántas y cuán grandes cosas habían pasado y visto en su viaje subterráneo, que había durado mil años; y las que venían del cielo hablaban de su bienaventuranza y de visiones de indescriptible hermosura» (República, 614d-615a). Tras tener estas visiones, Er fue devuelto a la tierra, pero dijo que no sabía cómo había regresado al cuerpo físico: «Y, una vez que se habían acostado y eran las horas de la medianoche, se produjo un trueno y temblor de tierra y al punto cada uno era elevado por un sitio distinto para su nacimiento, deslizándose todos a manera de estrellas. A él, sin embargo, le habían impedido que bebiera del agua, pero por qué vía y de qué modo había llegado a su cuerpo no lo sabía, sino que de pronto, levantando la vista, se había visto al amanecer yaciente en la pira» (República, 221b).

Plutarco de Queronea (c. 50-125) es el autor de un relato basado en la experiencia en el umbral de la muerte de un tal $A_{\text {rideo }}{ }^{41}$ de Solos que, al caerse de una gran altura, se golpeó el cuello y aparentemente murió, recuperando la vida tres días después. En efecto, según el relato de Plutarco, el alma de Arideo abandona su cuerpo a causa de la conmoción producida por una caída, sufriendo una transformación súbita y abrupta, parecida a la que sentiría un timonel «al verse lanzado del barco al abismo del mar» (De la tardanza de la divinidad en castigar, 563e). Después del choque inicial, el alma recobra la vista y el oído, disfrutando de su libertad y "su ser entero respiraba» (ibíd.). "Abriéndose su alma como un solo ojo. No veía nada de lo anterior [...] y se movía fácil y rápidamente en todas las direcciones" (De la tardanza de la divinidad en castigar, 563f). Esto le permitía contemplar el espectáculo de las almas de los muertos; como pompas de fuego que al explotar se convierten en formas humanas: «Unas saltaban con ligereza asombrosa y subían en línea recta, otras giraban en círculo [...] se movían en una

41 El nombre de Arideo es una variante de Ardieo el Grande, tirano, asesino de su padre y de su hermano mayor y numerosas tropelías, referido en uno de los Diálogos platónicos. Preso en el Erebo, recibía constantes y terribles castigos: «apaleándolos violentamente, los arrastraron al costado del camino y los desgarraron sobre las espinas» (República X, 616 a). Del mismo modo que Ardieo, Arideo es derrochador y desvergonzado. El oráculo de Anfíloco, en Cilicia, predice que será mucho más feliz después de la muerte. Pero Arideo volvió a la vida. Según Plutarco: «Al caerse de una altura sobre el cuello, aparentemente murió, aunque no de heridas sino sólo por el golpe. Al tercer día ya en los mismos funerales revivió. Recuperando rápidamente sus fuerzas y sus sentidos dio un cambio increíble a su vida. En efecto, los cilicios no conocieron por ese tiempo a otro más justo en sus tratos ni más piadoso con los dioses, ni tampoco más duro con los enemigos y firme con los amigos» (De la tardanza de la divinidad en castigar 563d). 
espiral confusa y desordenada» (De la tardanza de la divinidad en castigar, 564a). En este momento, aparece el alma de un pariente que aun niño se le aproxima y lo llama por su nuevo nombre, Tespesio.

La narración de Plutarco contiene siete momentos básicos ${ }^{42}$, que refieren el castigo de las almas y la «metensomatosis» de modo pormenorizado. El primer momento aparecen en escena los representantes de la justicia, Adrastea, hija de Ananke y de Zeus, y las Erinias, que adjudican las penitencias ajustadas a las diferentes categorías de infracciones.

El segundo momento se refiere a las "cicatrices y llagas causadas por las pasiones" (De la tardanza de la divinidad en castigar, 565c), un asunto que encontramos en Gorgias (523-524e) de Platón. Aquí se une con un evento quizá más interesante, poniendo en evidencia que las pasiones no sólo originan cicatrices, sino que también alojan otro tipo de huella en el alma, que sólo puede desaparecer por medio de una honda y concienzuda depuración en los dominios de Dikê (personificación de la justicia, entre los griegos); esta señal consiste en un color: «EI rojo oscuro y manchado es el color de la bajeza y la codicia; el rojo de sangre y fuego el de la dureza y la crueldad. Donde el color es azul grisáceo se ha borrado con dificultad cierta incontinencia en los placeres. Si se reúne, en cambio, malignidad con envidia, emite, como las sepias, un violeta engañoso» (ibíd.).

En el tercer momento, hallamos una clase de muertos especial: aquellos que fueron iniciados en los misterios de Dionisio en vida. En la vida futura ocupan su tiempo en la búsqueda de placeres y diversiones. Esta tarea provoca que el alma racional acumule humedad y se vuelva pesada: «la parte inteligente del alma se disuelve al humedecerse por el placer; la parte irracional y corporal, reanimada y reavivada, introduce el recuerdo del cuerpo. Pero del recuerdo se despierta un deseo y añoranza que arrastra al nacimiento que se llama así por ser inclinación a la tierra de un ala pesada por la humedad" (De la tardanza de la divinidad en castigar, 566a).

Un cuarto momento muestra que Plutarco fue también severo con Orfeo, que viajó al mundo de ultratumba para rescatar a su esposa Eurídice, pero no recordó bien lo que vio y dio una información incorrecta a los hombres: «El guía de Tespesio le dijo que hasta ese lugar había llegado Orfeo cuando iba tras el alma de su mujer pero, al errar en su memoria, había difundido entre los hombres un relato falso" (De la tardanza de la divinidad en castigar, 566b-c).

Un quinto momento tiene como objetivo destacar que ningún ser ha visitado una región que esté encima de la luna: «Y el demon dijo que la voz era de la Sibila. En efecto, ella cantaba el porvenir mientras giraba ante el rostro de la luna. El hubiera querido oír más cosas pero fue rechazado, como en los remolinos, por el impulso de la luna» (De la tardanza de la divinidad en castigar, 566d-e). La región de Apolo, que debe ser el sol, está bastante lejos del lugar visitado por Tespesio: "“Ya no sé", dijo, "si podrás ver el oráculo de Apolo. Pues la amarra del alma no da

42 Véase I.P. Couliano, Más allá de este mundo, Paidós, Barcelona, 1991, pp. 156-159. 
de sí ni cede hacia arriba, sino que tira hacia abajo atada al cuerpo» (De la tardanza de la divinidad en castigar, 566d).

En un sexto episodio se describen los castigos que reciben familiares, amigos y compañeros por parte de sus verdugos. Tespesio contempla a su propio padre sufriendo torturas: «se encontró con que amigos, familiares y compañeros recibían los castigos [...] Por último, vio cómo su propio padre, lleno de estigmas y llagas, subía desde un foso tendiéndole los brazos» (De la tardanza de la divinidad en castigar, 566e).

El séptimo y último momento conduce a Tespesio al lugar en el que las almas adoptan el tipo de cuerpos adecuados para regresar a la tierra: «Vio por último que las almas volvían a un segundo nacimiento, al ser forjadas violentamente en animales de toda índole y moldeadas por los artesanos encargados de ello" (De la tardanza de la divinidad en castigar, 567e). En un principio, el alma de Nerón estaba destinada a animar el cuerpo de una víbora nicándrica, pero una voz ordenó transformarla en otro animal menos agresivo: «Cuando la habían configurado ya los artesanos como una víbora nicándrica, en la cual iba a vivir devorando a su madre, brilló de pronto una gran luz y de ella salió una voz que ordenaba transformarla en otra especie más pacífica» (De la tardanza de la divinidad en castigar, 567f). En ese momento, como succionada por un aire intenso, el alma de Tespesio regresó a su cuerpo, impidiendo que el entierro siguiera adelante: «arrastrado repentinamente, como a través de un sifón, por un aire muy fuerte y violento, cayó en su cuerpo y abrió los ojos al pie de su misma tumba» (De la tardanza de la divinidad en castigar, 568a).

Ovidio, en su Metamorfosis (XV, 165-168), se refiere claramente a la transmigración: «El espíritu va errante y pasa de allí para acá y de aquí para allá ocupando cualesquiera miembros, y de los animales se traslada a los cuerpos humanos y a los animales el que era nuestro, y no perece».

Antes del final del paganismo romano, Salistio (c. II a.C.) compuso un tratado titulado Acerca de los dioses, en el que defendía la transmigración de las almas: «»Si la transmigración tiene lugar en un ser racional, el alma se convierte en el alma de ese cuerpo; si tiene lugar en una criatura irracional, el alma lo acompaña desde fuera, como lo hacen con nosotros nuestros espíritus custodios. Un alma racional jamás podría habitar una criatura irracional». Como prueba del hecho, toma como ejemplo el nacimiento de niños con enfermedades congénitas. Además, si el número de almas no fuese limitado, Dios debería hacer otras nuevas continuamente, o bien debería haber un número ilimitado desde el principio, lo que a Salistio le parece absurdo. Se respaldaba en el argumento de que Dios, siendo perfecto, debía haber hecho un mundo perfecto y era impensable que le hiciera constante añadidos, aunque esto es prejuzgar en cuanto a la potestad divina. Que haya un mundo ilimitado de almas en un mundo limitado no implica una contradicción, si por «ilimitado» uno entiende meramente un número que los hombres son incapaces de estimar ${ }^{43}$.

43 J. Crehan, «Las sociedades del Cercano Oriente», en VV.AA., ob.cit., p. 134. 
Los griegos creían que la inmortalidad era una cualidad ante todo de las divinidades y por eso los llamaban los Inmortales. Por su parte, Platón trata de demostrar que la inmortalidad es una prerrogativa del alma humana: «Porque todo cuerpo, al que le viene de fuera el movimiento, es inanimado; mientras que al que le viene de dentro, desde sí mismo y para sí mismo, es animado. Si esto es así, y si lo que se mueve a sí mismo no es otra cosa que el alma, necesariamente el alma tendría que ser ingénita e inmortal» (Fedro 245e-246a). Para el gran filósofo griego, la muerte afecta exclusivamente al cuerpo: «Al sobrevivirle entonces al ser humano la muerte, según parece, lo mortal en él muere, pero lo inmortal se va y se aleja, salvo e indestructible, cediendo el lugar a la muerte» (Fedón, 106e).

En el Fedro, Platón expone una doctrina completa sobre el ser humano, en la que puede observarse el influjo de la doctrina órfica. El filósofo griego expone su idea de una situación primordial en la que las almas, divinas e inmortales por naturaleza, no están preparadas para salvaguardar su elevación original, y se van desplomando hasta hallar una morada sólida (los cuerpos materiales) en que pararse. Fruto de ello es la transmigración tanto en cuerpos animales como humanos, con lo que las almas pierden su pureza. El filósofo es la persona que conoce todo lo relativo a este asunto y los medios para liberar su alma y devolverla a su estado original.

En De Republica Cicerón argumentó, contra los epicúreos, que el alma era inmortal, acudiendo a elementos pitagóricos y platónicos. Cicerón culminó su obra con el Sueño de Escipión en el que se afirma: «Esfuérzate, y ten por cierto que sólo es mortal este cuerpo que tienes, y que no eres tú el que muestra esta forma visible, sino que cada uno es lo que es su mente y no la figura que puede señalarse con el dedo. Has de saber que eres un ser divino, puesto que es dios el que existe, piensa, recuerda, actúa providencialmente, el que rige, gobierna y mueve ese cuerpo que de él depende, lo mismo que el dios principal lo hace con este mundo, y del mismo modo que aquel mismo dios eterno mueve un mundo que es, en parte, mortal, así también el alma sempiterna mueve un cuerpo caduco» $(\mathrm{VI}, 24)$. Es posible que Cicerón tomara aquí de Poseidonio, la doctrina de la transmigración de las almas, que se van encarnando en diferentes cuerpos mortales, siendo ellas mismas de naturaleza divina.

El intento de frenar el envejecimiento y conseguir la eterna juventud, rescatar de las fauces de la muerte a un ser querido o conseguir la inmortalidad son los temas centrales de diversas historias, narraciones míticas y épicas de la antigua Grecia: Hércules busca las manzanas de oro del jardín de las Hespérides, pero fracasa en su intento de conseguir la inmortalidad. Aquiles ${ }^{44}$ lo recuerda y acepta quedarse sólo con la gloria: «Ni tan siquiera Heracles de coraje valeroso, él que, preci-

${ }_{44}$ Aquiles, héroe de varias epopeyas, es quizá el personaje más estudiado de la llíada, poema épico griego atribuido a Homero. Prototipo de la belleza gimnástica, hijo de Peleo, rey de los mirmidones, y de la nereida (ninfa de los mares interiores) Tetis, fue sumergido por su madre en la laguna Estigia, ya que así se convertiría en inmortal; para hacerlo, le sujetó por el talón, que no se mojó y, por ello, era su único punto mortal. En la guerra de Troya, una flecha del héroe troyano Paris le hirió precisamente en el talón, causándole la muerte. 
samente, queridísimo era para Zeus [...] pero ahora ojalá yo conquistara valioso renombre» (Ilíada, XVIII, 115-121). Para Platón, la fama de la persona es una forma de inmortalidad al pervivir en el recuerdo de los vivos (Menexeno, 248c; Leyes, 927c).

Orfeo, mítico cantor tracio, hijo de Eagro, rey de Tracia y de la musa Calíope (o, según otras versiones, hijo de Apolo y de la musa Clío), era un músico y un poeta de gran talento, cuyo canto producía efectos extraordinarios. Quizá el más conocido de los episodios de su mito es el de su descenso a la morada de los muertos ${ }^{45}$ para rescatar de las fauces de la muerte a Eurídice. Supo conquistar de tal modo a las deidades infernales, que éstas le permitieron llevarse a su esposa con la única condición de que no volviera la cabeza para mirarla durante su regreso. Faltaba muy poco para llegar a las puertas del reino de los muertos, cuando Orfeo, cediendo a su amor y olvidando la condición fatal, se volvió a mirar a su esposa. Instantáneamente ésta fue tragada por las sombras y desapareció para siempre: «Vencido por su pasión, se volvió y la miró. Perdióse entonces el fruto de todas sus penas, quedó roto el pacto con el tirano cruel, y por tres veces dejóse oír un gran clamor en los lagos del Averno [...] He aquí que por segunda vez, se apoderan de mí los crueles destinos, y el sueño de la muerte cierra mis ojos apagados. Adiós, pues. ¡Me veo elevada por una oscura noche que me rodea, mientras tiendo hacia ti mis débiles manos, y me dispongo a no ser ya más tuya! [...] como el humo que se disipa en el aire impalpable, se alejó de sus ojos, desapareciendo. En vano quiso Orfeo asir lo que era una sombra» (Geórgicas, IV, 490-495).

Cicerón describe de este modo las antiguas creencias latinas ${ }^{46}$ : «en aquellos latinos, a los que Ennio llama casci, se hallaba enraizada la creencia de que en la muerte persistía la sensibilidad y de que, al abandonar la vida, el hombre no se destruía hasta el punto de perecer por completo» (Disputaciones Tusculanas, I, 12,27). En términos similares se expresa Tácito en el capítulo 46 de su Vida de Agrícola: «Si hay un lugar para los mânes de los hombres justos; si, como sostienen los filósofos, las grandes almas no se extinguen con el cuerpo, descansa en paz». En Elegía, IV,7, el poeta latino Propercio (s. I d.C.), que redactó sus poemas bajo el impulso de una pertinaz obsesión por la muerte, afirma que los Manes, existen y que la muerte no es el final de todo: «La muerte no es el fin de todo, y una pálida sombra venció y escapó de la pira». Asimismo describe la visión que tuvo de Cynthia, su amada muerta: «Sus cabellos y sus ojos eran los mismos que cuando

45 El mito de Orfeo, y sobre todo su breve estancia en las moradas infernales, fue el origen de la teología órfica, de carácter esotérico y mistérico, que giraba en torno a la espiritualidad y a la liberación del alma y que presentaba importantes matices filosóficos. Véase E. Rohde, ob.cit., pp. 479-500.

46 «Faltaba a los romanos la creencia en la inmortalidad personal. Sabemos que Cicerón, aunque gracias a sus estudios pudo llegar a adquirir este convencimiento, albergaba sus dudas sobre este punto. En opinión de Horacio, la supervivencia sería deparada a los labios de aquellos que recitaran sus poesías - non omnis moriar-, en tanto que el cuadro que del mundo futuro traza Virgilio en el libro sexto está lleno de dudas. Según Lucrecio, cuando el hombre corriente pensaba en la vida futura, veía ante sí un estado de padecimientos y miserias lleno de horrores; ésta puede haber sido la concepción habitual». T. Corbishley, «La religión de los romanos», en F. König, Cristo y las religiones de la tierra, Biblioteca de Autores Cristianos, vol. II, Madrid, 1960, p. 152. 
fue depositada sobre la tumba: sus ropas estaban chamuscados por un lado, y el fuego había roído el berilio familiar de sus dedos, y el agua del Leteo había secado sus labios".

En la Eneida (6,735-751), Virgilio adoptó un punto de vista pitagórico en cuanto a la condición de los muertos. El alma, al morir, ascendía a través del aire, luego atravesaba las aguas que hay sobre el aire, y al fin recorría la atmósfera que está directamente expuesta a los rayos del sol. Este viaje implicaba una purificación del alma mediante el aire, el agua y la radiación solar, de modo que estuviera totalmente limpia al acceder al Elíseo. Aquí podía quedarse o bien ser conducida al río Leteo para afrontar una nueva existencia en la tierra. La filosofía estoica había introducido esta noción de un ritmo cíclico en la vida del mundo; los más perversos regresaban del ciclo para padecer un castigo eterno, otros alcanzaban el eterno júbilo, pero la gran mayoría de los hombres atravesaba un proceso de vida, muerte, purificación y resurrección, en tanto que el mundo material era renovado cada mil años. Los epicúreos, por contraste, negaban la inmortalidad. 